IJLR: International Journal of Law Recontruction

Volume 5, Number 2, September 2021

DOI : http://dx.doi.org/10.26532/ijlr.v5i2.17545

\title{
THE LEGAL ACT ON COUNTERFEITING THE COVID-19 VACCINE IN
} INDONESIAN HEALTH LAW

\author{
Sahuri Lasmadi \\ Universitas Jambi \\ slasmadi@gmail.com
}

\begin{abstract}
The International Criminal Police Organization has officially issued a global warning to law enforcement officials in 194 member countries to prepare to prevent and deal with various world criminal networks that will seek to utilize the Covid-19 vaccine, both physically. The online form is counterfeiting the Covid-19 vaccine. This study aims to analyze the criminal act of counterfeiting the Covid-19 vaccine from the Health Law in Indonesia. The research method used is the Normative Law research method, which examines library materials or secondary data. Normative legal research is also called doctrinal legal research. The criminal act of counterfeiting the Covid-19 vaccine is generally regulated in Article 386 Paragraph 1 of the Criminal Code relating to acts of fraud and forgery. However, it is specifically regulated in the provisions regarding penalties for distributing fake vaccines in Indonesia as regulated in Articles 196, 197, 198, and 201 Act No. 36 of 2009 concerning health. The ingredients are everyone deliberately and producing and circulating counterfeit vaccine preparations. For the criminal act ofCovid-19 vaccine counterfeiting corporate, the corporation can be subject to additional penalties in the form of revocation of business licenses and revocation of legal entity status.
\end{abstract}

Keywords: Covid-19; Crime; Health; Law.

\section{A. INTRODUCTION}

Coronaviruses (CoVs) cause severe respiratory and gastrointestinal infections transmitted through hosts like humans, mammals, fish, and avians. The emergence of Severe Acute Respiratory Syndrome coronavirus (SARS-CoV) outbreaks in 2002-2003 were followed by Middle East Respiratory Syndrome (MERS-CoV). The recently found $\mathrm{CoV}$ is named SARS-CoV 2 as it shows some resemblance towards the SARS-CoV. ${ }^{1}$ The effect that COVID-19 has had on small and enormous organizations is something never found more than five ages. Authentic records of joblessness filings have made the route for H.R. a one-of-a-kind test. As these suggestions have been instituted, it has constrained managers to settle on extremely troublesome choices -

1 Rithiga, S. B., \& Shanmugasundaram, S, Virtual Screening of Pentahydroxyflavone - A Potent COVID-19 Major Protease Inhibitor, Asian Journal of Research in Pharmaceutical Sciences, Volume 11, Nomor 1, 2021, page.7-14; 
incidentally, close the entryways, change business activities, convert business tasks to telecommute, leave absence workers, or lay off representatives. ${ }^{2}$

Currently, the Covid-19 Vaccine is being distributed to all Indonesians. This vaccine is a solution that is considered the most appropriate to reduce the number of cases of the SARS-CoV-2 virus infection that causes Covid-19 disease. Since the Covid-19 vaccine arrived in Indonesia, few people have not agreed to the government's recommendation to undergo the Covid-19 vaccination. Giving this vaccine is very important to protect the people from Covid-19 and restore countries' social and economic conditions affected by the Pandemic. ${ }^{3}$

Vaccination or immunization aims to make a person's immune system recognize and quickly fight the bacteria or virus that causes infection. The goal to be achieved by giving the Covid-19 vaccine is to reduce the morbidity/mortality rates due to this virus. ${ }^{4}$ Although not $100 \%$ can protect a person from Coronavirus infection, this vaccine can reduce the possibility of severe symptoms and complications due to Covid-19. Besides, the Covid-19 vaccination aims to encourage the formation of herd immunity or group immunity; this is important because some people cannot be vaccinated for some reason. People who are not recommended to receive the vaccine or are not a priority for the Covid-19 vaccine include children or adolescents under 18 years of age and people who suffer from certain diseases, such as diabetes or uncontrolled hypertension ${ }^{5}$

Health issues, such as the implementation of the Covid-19 Vaccine, are economically attractive. Therefore it is not uncommon for situations like this to be exploited by irresponsible people to reap improper benefits. Today's society is fascinated with crime and justice. It is an age in which high crime rates and high levels of concern about crime have become accepted as 'normal' (Ghosh, 2014). From this issue, the International Criminal Police Organization officially issued a global warning to law enforcement officials in 194 member countries to prepare to prevent and deal with various world criminal networks that will try to take advantage of the Covid-19 vaccine both physically and online. The 'Orange Warning' from the International Criminal Police Organization describes potential crimes such as theft, counterfeiting, and the organized illegal marketing of the Covid-19 vaccine. ${ }^{6}$ This Pandemic that is sweeping the entire

2 Sambrani, Vinod. N., \& Rao, C. S. A, Covid 19 is a Curse to Hospitality Industry, International Journal of Advances in Social Sciences, Volume 8, Nomor 4, 2020, page.235-241.

3 Kaur, S. P., \& Gupta, V, COVID-19 Vaccine: A Comprehensive Status Report, Virus Research, 2020, page.1-12.

4 Lee Ventola, C, Immunization in the United States: Recommendations, Barriers, and Measures to Improve Compliance: Part 1: Childhood Vaccinations, $P$ and T, Volume 41, Nomor 7, 2016, page.426-436.

5 Clemente-Suárez, V. J., Hormeño-Holgado, A., Jiménez, M., Benitez-Agudelo, J. C., NavarroJiménez, E., Perez-Palencia, N., Maestre-Serrano, R., Laborde-Cárdenas, C. C., \& TorneroAguilera, J. F, Dynamics of Population Immunity Due to the Herd Effect in the COVID-19 Pandemic, Vaccines, Volume 8, Nomor 2, 2020, page.1-20.

6 Interpol, INTERPOL Warns of Organized Crime Threat to COVID-19 Vaccines, 2020, Interpol.Int. 
world is being watched for an unprecedented potential for criminal behavior. International Criminal Police Organization's Orange Warning is a warning of an event, person, thing, or activity that is considered a severe threat to public safety. In the commemoration, the International Criminal Police Organization included crimes where some people began advertising, selling, and applying fake vaccines.

Cases of counterfeiting Covid-19 Vaccines are currently occurring in China. Chinese authorities are taking serious action against crimes related to the Covid-19 vaccine in their country. Dozens of people were reportedly arrested over the production and distribution of counterfeit Covid-19 vaccines, price inflation, and illegal vaccinations. Authorities in China arrested at least 70 suspects. Twenty-one cases related to the Covid-19 vaccine. The majority of cases occurred during the initial phase of the vaccine launch. ${ }^{7}$

The issue of vaccine counterfeiting is not a very health issue but also a legal issue, considering that the law orders' main objective. This need for order is a fundamental condition for the existence of an orderly human society. Apart from order, another goal of the law is to attain justice, which varies in content and size according to society's era of order society, efforts are made to ensure that the interaction between humans in society is essential not only for an orderly society but is an absolute requirement for an organization of life that transcends the present boundari. ${ }^{8}$ That is why legal institutions, such as marriage, property rights, and contracts, including those in the health sector.

Indonesia has experience related to vaccine counterfeiting. For example, the perpetrators of the fake vaccine maker named Hidayat Taufiqurahman and Rita Agustina, other actors act as agents. These include forged vaccines Engertx B Vaccine, Pediacel Vaccine, Euvax B Vaccine, Tripacel Vaccine, Tyberculin PPDRT 23, Penta-Bio Vaccine, T.T. (tetanus) Vaccine, Measles Vaccine, Hepatitis $B$ Vaccine, Bopv Polio Vaccine, Vaccine BCG and Harvix Vaccine. From the confessions of the perpetrators of fake vaccines, it has spread in Indonesia since 2003. This case was revealed from public information and news media about a baby who died after being immunized. Besides, it was found that many children whose conditions were health disturbed after being given vaccines, and there were reports of suspicious delivery of vaccines for under-five at several health centers. From this case, the Indonesian government continues to be vigilant by creating various regulations as rules of the game in dealing with the possibility of counterfeiting the Vaccine Covid-19.

To determine the perpetrator of the criminal act of Covid-19 vaccine counterfeiting, one must map the pattern of the series of criminal acts. Legal responsibility can be reached both in terms of intent (do/us) and negligence

7 Bhaya, A. G, China Busts Fake COVID-19 Vaccine Ring, Arrests 80, Confiscates 3,000 Doses, 2021, CGTN.

8 Pound, R, Justice According to Law, Columbia Law Review, Volume 13, Nomor 8, 1913, page.696-713. 
(culpa) of each series from this realm. Seeing the patterns that occur in various places and various regions, it can be concluded that the series of "players" are pretty sophisticated and evenly patterned.

Before determining criminal liability, it must be legally proven whether the "fake vaccine" is not under health regulations. Pharmaceutical supplies do not meet standards, efficacy/benefits, and quality proven scientifically. The results of the analysis from a health perspective must prove before seeing accountability. From the health analysis results, the "users" such as hospitals and clinics were determined. Is it due to buying at a price that is below standard or receiving "something" such a bonus for the marketing of fake vaccines so that the perpetrator can then qualify as a "perpetrator."

Concerning fake vaccines as a legal issue, Indonesia already has a special regulation on health, namely Act No. 36 of 2009. This law recognized that health is a human right and one of the elements of welfare that must be realized under the ideals of the Indonesian people referred to Pancasila (Five Principles of the Indonesian State) and the 1945 Constitution of the Republic of Indonesia. ${ }^{9}$ Health problems, such as counterfeit vaccines, which cause health problems to the Indonesian people, will cause substantial economic losses for the country, and any efforts to improve the degree of public health also mean investment in the country's development. Therefore, the state has the responsibility to curb people who fake vaccines through legal means. This study analyzes the criminal act of counterfeiting the Covid-19 Vaccine from Health law in Indonesia from the problems above.

\section{B. RESEARCH METHODS}

This research is research in the field of law. The research method used is normative juridical research or doctrinal law research. Normative Legal Research is legal research conducted by examining library materials or secondary data. Normative legal research is also called doctrinal legal research. ${ }^{10}$ According to Peter Mahmud Marzuki, normative legal research is a process to find the Rule of Law, legal principles, and legal doctrines to answer legal issues at hand. ${ }^{11}$ The juridical approach is based on a normative approach in which research in legal discovery efforts concrete. ${ }^{12}$ In this type of legal research, the law is often conceptualized as written in statutory regulations/the law is drafted as a rule or norm, a benchmark for human behavior deemed appropriate. The data used is secondary data, which is data obtained from

9 Fitriani, E, Fake Vaccine in Children and The Protection, Journal La Sociale, Volume 1, Nomor 5, 2020, page.28-32.

10 Kharel, A, Doctrinal Legal Research, SSRN Electronic Journal, 252, January, 2018, page.1-16.

11 Heronia Nendissa, R, Understanding Pancasila in Pela Gandong Culture in Maluku, International Journal of Advanced Research, Volume 8, Nomor 7, 2020, page.748-752.

12 Nugroho, D. R., \& Noho, M. D. H, Kajian Yuridis Kewenangan Pemerintah untuk Memerintahkan Melakukan Merger kepada Entitas Bank pada masa Wabah Covid19 dalam Rezim Perdagangan Internasional, Cakrawala Hukum, Volume 22, Nomor 2, 2020, page.17. 
literature studies. ${ }^{13}$ Secondary data is to find initial data or information, get a theoretical or legal basis, and obtain limitations, definitions, and meanings of a term. This research is analyzed qualitatively, namely intensive activities that require deep understanding, creativity, and conceptual sensitivity, and the analysis results will be presented in a descriptive form. This research ${ }^{14}$

\section{RESULTS AND DISCUSSION}

\section{Overview of the Covid-19 Vaccine in Indonesia}

From an earlier moment in time and within endless ages, the globe is persistently tested by awful agonies of pandemics. The obscure infections (virus) assaulting human being's development from the old ages. An excessive number of individuals and civic establishments need to take care of different pandemics. Along these lines, a requirement for cognizant and perceptional understanding between individuals, municipal establishments, and the working governments of the world needs to approach humanity is upholding from its elimination. The existing data marks the casualties of more than 500 million human lives-the more civilized. Additionally, the boom in the technological era within communication networks and approachable transport medium oversees smooth transit of cross-cultural migrations, and people became advanced with more prominent urban communities, increasingly fascinating exchange courses, and expanded contact with various populaces of individuals, creatures, and environments. ${ }^{15}$

World Health Organization (WHO) states that "health is a state of complete physical, mental and social well being not merely the absence of disease or illness" ${ }^{1}$. It is affected by a wide range of physical, mental, social, and political factors. All these factors are responsible for better health conditions and quality of life as they relate to each other if one is hampered and affects others. It has been reported that 5 million children were dying each year, and another 5 million were disabled by infectious diseases. ${ }^{16}$

On February 11, 2020, the WHO officially called the disease triggered by 2019-nCoV Corona Virus Disease 2019 (Covid-19. ${ }^{17}$ The spread of Covid-

13 Edytiawarman, E., Muljono, S., \& Arso, D. D, Case Study of Claim Against Violence in Household in Religion Court of Class I a Bengkulu, Bengkoelen Justice: Jurnal IImu Hukum, Volume 10, Nomor 1, 2020, page.123-140.

14 Natalis, A., Urgensi Kebijakan Penyelenggaraan Anggaran Pendapatan dan Belanja Daerah dalam Mewujudkan Kesejahteraan Perempuan, Pandecta Research Law Journal, Volume 15, Nomor 1, 2020, page.64-73.

15 Sinha, G, The vista of Pandemic in the world and its adaptation by Society: Statistical significant precautions on COVID, Asian Journal of Management, Volume 11, Nomor 4, 2020, page.453456.

16 Yadav, R, Vaccines Other Than Specified in National Immunization Schedule among Parents of under- five Children, International Journal of Advances in Nursing Management, Volume 3, Nomor 1, 2015, page.64-68.

17 Lai, C. C., Shih, T. P., Ko, W. C., Tang, H. J., \& Hsueh, P. R, Severe A Respiratory Syndrome Coronavirus 2 (SARS-CoV-2) and Coronavirus Disease-2019 (COVID-19): The Epidemic and the Challenges, International Journal of Antimicrobial Agents, Volume 55, Nomor 3, 2020, page.1-4. 
19 then continued rapidly until many countries were infected with Covid19. ${ }^{18}$ Until January 30, 2020, WHO declared the Covid-19 outbreak in China a Public Health Emergency, a world that indicated that concern for the Covid-19 was a global threat to the world. A novel coronavirus outbreak has spread globally; as of May 2, 2020, more than 3.35 million cases have been reported across 187 countries and territories, resulting in more than 238,000 deaths. More than 1.05 million people have recovered. ${ }^{19}$ The emergency committee has stated that the spread of Covid-19 can be stopped if protection, early detection, isolation, and fast treatment are carried out to create a healthy system implementation to stop the spread of Covid-19.20 Given this, as an effort to protect against Covid-19, various countries worldwide have committed together by involving governments, biotech companies, scientists, and academics to create a Covid-19 vaccine. So far, many vaccine candidates have been launched against the SARS-CoV-2 virus, the cause of Covid-19.

Before modern medicine, the only way to develop immunity was to become infected by an infectious agent and survive it. ${ }^{21}$ Vaccines have long been recognized as a substance used to elicit immune responses against pathogenic microorganisms. The vaccine was first discovered in 1796 by Edward Jenner, namely the smallpox virus vaccine. Since then, vaccine manufacturing technology has developed rapidly, and various vaccines to prevent infectious diseases have been widely used. ${ }^{22}$

Most of the effective vaccines used today resulted from the explosive growth of biomedical research after World War II. Enormous advances were made both in biological knowledge and in the capabilities of research tools, including computers and microscopes. For example, in the early 1900s, diphtheria caused more deaths in Australia than any other infectious disease. However, with the introduction of the diphtheria vaccine after World War II, diphtheria has virtually disappeared, the last case reported in $1993 .{ }^{23}$

18 Sun, P., Lu, X., Xu, C., Sun, W., \& Pan, B, Understanding of COVID-19 Based on Current Evidence, Journal of Medical Virology, Volume 92, Nomor 6, 2020, page.548-551.

19 Biradar, V., \& Dalvi, P, Impact of COVID19 on Child Health: Parents Perspective, International Journal of Nursing Education and Research, Volume 8, Nomor 4, 2020, page.463-467

20 Zhang, G., Yang, H., Zhang, A., Shen, Q., Wang, L., Li, Z., Li, Y., Zhao, L., Du, Y., Sun, L., Zhao, B., Zhu, H., Fu, H., Li, X., Gao, X., Hao, S., Ding, J., Chen, Z., Xu, Z., ... Li, Q, The Impact of the COVID-19 Outbreak on the Medical Treatment of Chinese Children with Chronic Kidney Disease (CKD) : A Multicenter Cross-section Study in the Context of a Public Health Emergency of International Concern, MedRxiv, 2020, page.1-17.

21 Visweswaran, V., Binoy, A., Sreenivas, A., Abhinand, B., \& Vijayan, M.,Vaccines-Pillars of Preventive Health, Research Journal of Pharmacy and Technology, Volume 10, Nomor 9, 2017, page.3205-3210.

22 Riedel, S, Edward Jenner and the History of Smallpox and Vaccinatio, Baylor University Medical Center Proceedings, Volume18, Nomor 1, 2005, page.21-25.

23 Aher, V. D., Banerjee, S., \& Mahaur, K. K, Vaccine: An Ultimate Way of Immunization, Research Journal of Pharmacy and Technology, Volume 4, Nomor 3, 2011, page.369-374. 
Conventional vaccines, both the first generation vaccines, namely vaccines containing live, weakened microorganisms, and the secondgeneration vaccines, namely vaccines containing killed microorganisms, and the third generation vaccines, namely recombinant vaccines, also known as sub-unit vaccines containing antigenic fragments of microorganisms that can stimulate an immune response, in its use it still has several drawbacks (Crommelin et al., 2013). ${ }^{24}$ The first generation of vaccines can often mutate back into virulent, causing unwanted effects. Therefore, usually, this type of weakened vaccine is not recommended for immune compromised patients. Meanwhile, the second-generation vaccine contains microorganisms killed using certain chemicals, usually using formaldehyde or phenol, which often fail or do not cause an immune response. ${ }^{25}$

To overcome the various weaknesses in the use of the first and second began to be developed vaccines, vaccine generation third generation, namely the recombinant vaccine known as the sub-unit vaccine. The subunit vaccine is made through genetic engineering techniques to obtain antigenic fragments from microorganisms, called a recombinant vaccine. For example, the hepatitis $B$ vaccine contains the protein-coated portion of the hepatitis $B$ virus produced through genetic engineering by yeast cells. ${ }^{26}$ Vaccines Recombinants are safer than vaccines containing all viral cells because the antigenic fragments in the recombinant vaccine cannot reproduce in the recipient's body. Besides that, recombinant vaccines generally do not cause side effects. However, a third-generation vaccine can only cause a humoral immune response and not a cellular immune response. ${ }^{27}$ Currently, it is clear that without in-depth knowledge of the nature of the pathogen, including a detailed study of the genome molecular organization, it is impossible to create highly effective means of etioprophylaxis. However, the progress in immunology and the design of new modern adjuvants, including nanoadjuvants, create preconditions for developing leading-edge vaccines ${ }^{28}$

The stages in making a vaccine go through several stages until the vaccine can be produced and accepted globally and the development of the Covid-19 vaccine. As the most effective and economical way to prevent infectious diseases, vaccines develop a vaccine to fight Sars-CoV-2 infection

24 Crommelin, D. J. A., Sindelar, R. D., \& Meibohm, B, Vaccines. Pharmaceutical Biotechnology, 27 2013, page.439-457.

25 Hanley, K. A, The Double-Edged Sword: How Evolution Can Make or Break a Live-Attenuated Virus Vaccine. Evolution: Education and Outreach, Volume 4, Nomor 4, 2011, page.635-643.

26 Laere, E., Ling, A. P. K., Wong, Y. P., Koh, R. Y., Mohd Lila, M. A., \& Hussein, S, Plant-based Vaccines: Production and Challenges. Journal of Botany, 2016, page.1-11.

27 Nascimento, I. P., \& Leite, L. C. C, Recombinant Vaccines and the Development of New Vaccine Strategies, Brazilian Journal of Medical and Biological Research, Volume 45, Nomor 12, 2012, page.1102-1111,

28 Abdualiyeva, A. A., Akhmetsadykov, N. N., Valdovska, A., \& Shanbaev, B. U, Improving the technology of obtaining an inactivated Antirabic vaccine from CVS-11 strain, Research Journal of Pharmacy and Technology, Volume 13, Nomor 12, 2020, page.5929-5934. 
indispensable. So far, more than 40 pharmaceutical companies and academic institutions around the world have launched their vaccine development programs against Sars CoV-2. ${ }^{29}$ Over the past two decades, three human-acquired coronaviruses (Sars-CoV, Mers-CoV, and Sars-CoV-2) appear worldwide, causing a significant threat to global health. However, there is still no approved vaccine for the human coronavirus. Research groups worldwide are accelerating the development of a Covid-19 vaccine using various approaches. ${ }^{30}$ The proper recognition mechanisms between viral surface proteins and host receptors are essential for understanding how cross-species and tropical hosts are transmitted and animal models for vaccine development. The spike coronavirus protein (S) is an essential target for vaccine development because it mediates the infection mechanism through binding to host cell receptors. ${ }^{31}$

After evaluating the results of Phase I and II CoronaVac clinical trials, the Food and Drug Administration recommends conducting phase III clinical trials in Indonesia to determine how far the vaccine's effectiveness raises specific antibodies against Covid-19 in Indonesia the potential for PostImmunization Follow-up Events. Implementation of the CoronaVac phase III clinical trial in Indonesia involves P.T. Bio Farma (Persero); Padjadjaran University Faculty of Medicine; National Agency of Drug and Food Control; and the Health Research and Development Agency the Ministry of Health. The CoronaVac clinical trial was carried out on volunteers by first carrying out a health check and swab test. Volunteers recorded until August 15, 2020, were 1,451 out of the target of 1,620 volunteers ranging in age from 18 to 59 years. Meanwhile, more than 100 volunteers have undergone the first injection of clinical trial III. Volunteers will be injected twice with an interval of 14 days. Monitoring of the effect and safety of the vaccine is carried out for the next six months.

When the phase III clinical trial is successfully carried out, vaccination will be carried out en masse for the Indonesian people. At least $70 \%$ of Indonesian people receive vaccines to form herd immunity. In June 2020, phase I and II clinical trials were conducted on 743 volunteers in China. As a result, there are no harmful effects, and CoronaVac can produce an immune response in volunteers. CoronaVac clinical trials are carried out in Indonesia and other countries such as Bangladesh, Turkey, Chile, and Brazil. In Brazil, phase III clinical trials involve 9,000 volunteers.

29 Ahn, D. G., Shin, H. J., Kim, M. H., Lee, S., Kim, H. S., Myoung, J., Kim, B. T., \& Kim, S. J, Current Status of Epidemiology, Diagnosis, Therapeutics, and Vaccines for Novel Coronavirus Disease 2019 (COVID-19), Journal of Microbiology and Biotechnology, Volume 30, Nomor 3, 2020, page.313-323.

30 Zheng, J, SARS-CoV-2: An Emerging Coronavirus that Causes a Global Threat, International Journal of Biological Sciences, Volume16, Nomor 10, 2020, page.1678-1685.

31 Singh, S. P., Pritam, M., Pandey, B., \& Yadav, T. P, Microstructure, Pathophysiology, and Potential Therapeutics of COVID-19: A Comprehensive Review, Journal of Medical Virology, Volume 93, Nomor 1, 2021, page.275-299 
Phase III clinical trials are the final stage of testing before the vaccine candidate is finally registered in the country of origin and obtains permission to be distributed in the market. In this regard, the Food and Drug Supervisory Agency has regulations on the approval of imported vaccines for distribution in Indonesia, such as Regulation of the Food and Drug Supervisory Agency Number 30 of 2017 concerning Supervision of the Importation of Drugs and Food into Indonesian Territory. This approval is a form of supervision pre-market carried out by the Food and Drug Administration. When circulated, the Food and Drug Supervisory Agency has the authority to carry out supervision post-market so that the marketed product is guaranteed safety, efficacy, and quality as submitted at registration at the Food and Drug Supervisory Agency. With this supervision pre-market and post-market, the Indonesian people will be protected from illegal vaccines, fake vaccines, and damaged vaccines. ${ }^{32}$

However, during this Pandemic, the Food and Drug Administration gave acceleration through permits in an emergency. The Food and Drug Administration will analyze the data from the results of these clinical trials. If they meet the requirements, the vaccine candidate will get a distribution permit. In line with the phase III clinical trial, P.T. Bio Farma (Persero) in October 2020 will start producing 10 million doses per month. The government has budgeted to provide vaccines of 30-40 million doses at P.T. Bio Farma (Persero), amounting to IDR 5 trillion this year and IDR 40-50 trillion for next year. CoronaVac is conducting phase III clinical trials in Indonesia from September 2020 to March 2021. A phase III clinical trial will be carried out on a vaccine candidate developed by the Genexine Consortium (South Korea) in collaboration with PT Kalbe Farma. Other efforts in obtaining the Covid-19 vaccine were also carried out through P.T. BHCT Biotechnology Indonesia in collaboration with China Sinopharm International Corporation. ${ }^{33}$

The following are some of the Covid-19 vaccines currently circulating in Indonesia:

a. Sinovac (CoronaVac)

CoronaVac is the name for the Covid-19 vaccine developed by a Chinese pharmaceutical company, Sinovac; this is the first vaccine that the Indonesian government has successfully obtained and is used to start a vaccination program. Vaccines are made using inactivated virus technology, aka using weakened viruses. P.T. Bio Farma's corporate secretary, Bambang Heriyanto, once predicted the Corona Sinovac

32 Satari, H. I., Puspita, M., Sundoro, J., Andrijono, Syafriyal, Sari, R. M., Bachtiar, N. S., \& Hadinegoro, S. R, Safety Profile of Td Vaccination in Indonesian Pregnant Women: A Postmarketing Surveillance Study, Medical Journal of Indonesia, Volume 28, Nomor 4, 2019, page.322-328.

33 Yuningsih, R, Uji Coba CoronaVac dan Rencana Vaksinasi Covid-19 Massal di Indonesia. In Info Singkat: Kajian Singkat Terhada isu Aktual dan Strategis, Vol.XII, No. 16, 2020 
vaccine price to be around IDR 200,000 per dose. The price of this vaccine ranges from IDR 200,000.00 (two hundred thousand rupiahs)

b. Novavax

The Novavax vaccine is a vaccine made by the United States company, Novavax, also used in Indonesia. President Jokowi said that there were 50 million doses of the Novavax Covid-19 vaccine; this vaccine is made by utilizing a small portion of the protein from the coronavirus used to infect cells. According to various sources, the Novavax vaccine is sold for around the U.S. \$ 16 or IDR 225,000 per dose.

c. AstraZeneca-Oxford

President Jokowi also announced that he would use 50 million doses of the Covid-19 vaccine developed by AstraZeneca-Oxford. This vaccine is made with technology utilizing a modified chimpanzee coldcausing virus (adenovirus). The virus is similar to SARS-COV-2, which causes Covid-19, but cannot cause disease. Various sources predict that the vaccine will AstraZeneca-Oxfordsell for around the U.S. \$ 4 or IDR 60,000 per dose.

d. Pfizer-BioNTech

The Covid-19 vaccine developed by Pfizer-BioNTech is the only vaccine that has received an emergency permit from WHO to date. President Jokowi said Indonesia would use 50 million doses of this vaccine. The Pfizer-BioNTech Covid-19 vaccine was made with messenger RNA (mRNA) technology. Vaccines do not contain live viruses. It is predicted that various sources will sell this vaccine for around U.S. \$ 19.50 or IDR 275,000 per dose.

e. Covax

Covax is an international non-profit organization formed by WHO, the GAVI Alliance, and the Coalition for Epidemic Preparedness Innovations (CEPI). The goal is to ensure that the Covid-19 vaccine is equally accessible to all countries. COVAX works by collecting various doses of the Covid-19 vaccine available, then distributing it to member countries. President Jokowi said that Indonesia received 54 million doses of vaccine from COVAX.

\section{The Criminal Act of Counterfeiting the Covid-19 Vaccine in the Perspective of Health Law in Indonesia}

As the rule of law aims to realize general welfare, every activity and is oriented towards the goals to be achieved must make the applicable law a rule of the state, government, and social activities. So, according to its essence, law plays a significant role in regulating every legal relationship between individuals and communities in various fields of life, including health.

Health law is a field of specialization in law that is relatively new in 
Indonesia. Health law includes all rules and regulations directly related to the maintenance and care of threatened or damaged health. Health law includes applying civil law and criminal law relating to legal relations in health services. ${ }^{34}$

In the state, the law that has increased towards a welfare state becomes the state's obligation with the means of equipment to create conditions for life. Life for everyone, family, and society is prosperous. According to articles 1-6 of Act No. 9 of 1960, which have been revised by Act No. 23 of 1992 then revised again by Act No. 36 of 2009 concerning Health, health workers or doctors are actively involved in health efforts done by the government. Government health efforts that involve health workers as the authorized state apparatus constitute the development of constitutional law aspects in health medical law.

However, recently there have been frequent cases of crimes in the health sector. For example, drug counterfeiting, cosmetic counterfeiting, formalin-based foods, and recently fake vaccines whose victims are children will grow and develop into the next generation who can be expected as a pillar foundation of parents, family, community, nation, and state. Various crimes are committed in society, and some are very heinous, while others may be of a minor kind. However, some crimes or acts are of such nature that threatens the very culture, belief, or basis of establishing a civilized society. ${ }^{35}$

In the early part of the present century, it was a prevalent notion that criminality is hereditary. According to this notion, those who commit have particular criminal traits in connection with this contention. We can mention the Hobrosian doctrines, which maintain a close relationship between physical structure and criminal behavior. Lambroso and his followers have compared criminals and savages, and they conclude that criminals are born. Dugdale and Estabrook have extensively used family trees to prove that criminality is inherited. A study by Dugdale and Estrabrook thus pointed out that criminal traits appear in successive generations. In his study of family history, Karl Rath has attempted to demonstrate that criminality in successive generations appears by Mendelian ratio. Lambroso and his followers have insisted that criminals have certain physical traits. According to them, criminals are characterized by a certain stigma. So then, the criminal constitutes an inferior biological type.

Similarly, according to Hootan, there are differences between prisoners and nonprisoners. He concludes that the primary cause of crime is biological

34 Iswandari, H. D, Aspek Hukum Penyelenggaraan Praktik Kedokteran: Suatu Tinjauan Berdasarkan Undang-Undang No. 9/2004 Tentang Praktik Kedokteran, Jurnal Manajemen Pelayanan Kesehatan, Volume 9, Nomor 2, 2016, page.52-57.

35 Kumar, S, Decriminalization of Adultery: A Step Towards Rights Based Social Relations, Research Journal of Humanities and Social Sciences, Vol.10, No.2, 2019, page.553-558. 
inferiority. ${ }^{36}$ Since the inception of human society, crime has been a common occurrence (though not necessarily socially accepted). Emile Durkheim puts it as an "integral part of all healthy societies." Therefore crime is said to be a fundamental condition of social organization. ${ }^{37}$

The science of criminal law distinguishes three kinds of intentionality, namely deliberate intent, deliberate certainty, and deliberate action as a possibility. ${ }^{38}$ Intentions as intent (opzet als oogmerk) are intentions to achieve an immediate goal. That is, between the motivation of someone who does an action, the action and the result are manifested. A person's motivation significantly affects his actions. ${ }^{39}$

Intentional as certainty (opzet met zekerheidsbewustzijn), in contrast to intention as intention, deliberate as certainty or necessity is deliberate, which has two consequences. The perpetrator wants the first effect, while the second result is unwanted but certain or must occur. Deliberate as a possibility (dolus eventualis), sometimes deliberate cause is not specific, but it is possible. In such a case, there will be deliberation with an awareness of the possibility. Dolus eventualis was born because of a condition where the perpetrator's inner attitude where the perpetrator does not want a goal to realize a criminal act, but the circumstances that cause him cannot escape a particular situation. ${ }^{40}$

Crimes regarding counterfeiting are crimes that contain elements of an untruth or false state of something (object), in which something is only from the outside as if it is true even though it contradicts the truth. The crimes committed by the alleged perpetrators of counterfeiting and distribution of fake vaccines, which recently caused this commotion, also violated Article 386 Paragraph 1 of the Criminal Code related to fraud and forgery and violated Act No. 36 of 2009 concerning Health has distributed unsafe and unqualified vaccines. It is known that the perpetrators used anti-tetanus solution mixed with intravenous fluids as the basis for the fake vaccine. The two liquids are then put into a used bottle. Furthermore, the place where the fake vaccine is made is not feasible.

Regulations regarding the safety and use of vaccines in Indonesia are regulated in Article 98, Article 104, Article 105, Article 106, Article 108, Act No. 36 of 2009 concerning Health. Article 98 stipulates that pharmaceutical preparations and medical devices must be safe, nutritious/beneficial, good

36 Gulpham, S, Biocrime: Neurochemicals in Criminal and Anti-Social Behavior, Research Journal of Science and Technology, Volume 3, Nomor 4, 2011, page.217-219.

37 Deshmukh, A, Victim Rights in Indian Criminal Justice System: A Comparative Study, Research Journal of Humanities and Social Sciences, Volume 11, Nomor 2, 2020, page.157-163.

38 Erlandi, G. A, Penyelesaian Perkara Tindak Pidana Terkait Penghinaan Agama, Jurist-Diction, Volume 1, Nomor 2, 2019, page.537-556

39 Neuman, P, Some Comments on the Distinction between Intention and Intentionality, Behavior Analyst, Volume 30, Nomor 2, 2007, page.211-216.

40 Rakovec-Felser, Z, Domestic Violence and Abuse in Intimate Relationship from Public Health Perspective, Health Psychology Research, Volume 2, Nomor 3, 2014, page.62-67. 
quality, and affordable. Everyone who does not have the expertise and authority is prohibited from procuring, storing, processing, promoting, and circulating drugs and medicinal ingredients. Provisions regarding the procurement, storage, processing, promotion, distribution of pharmaceutical preparations and medical devices must meet the quality standards of pharmaceutical services stipulated by government regulation. The government is obliged to guide, regulate, control, supervise the procurement, storage, promotion, and distribution.

Several factors need to be considered in the plan for mass vaccination in 2021. First, it is necessary to do massive socialization about the importance of vaccination as the most effective effort to prevent the disease and the dangers of the Covid-19 Pandemic from various life perspectives. Efforts Dissemination involving all stakeholders, including the Indonesian Ulama Council (MUI). Over halal vaccines in emergencies that threaten human life. Thus, the Indonesian Ulama Council can mobilize religious figures in the regions to participate in socializing the local community. The socialization also involved all community elements, involved local area managers, involved schools, and others. Socialization also involves all mass media and social media because many media mistakenly report that the Covid-19 vaccine and drug are the same even though they are different. Vaccines aim to prevent disease, while medicine aims to heal when contracted diseases.

Social media involvement is essential, considering that people are more exposed to social media than news on television or in newspapers. Moreover, recently there was a case of a YouTuber who created false content and hoaxes that herbal medicine can cure Covid-19 patients in a matter of days and prevent the disease. To prevent hoaxes, the government plays a role in education and outreach to the public. Second, the approach to the group anti-vaccine. As in the immunization activities of several previous infectious diseases, which brought many pros and cons of halal and led to anti-vaccine groups, Covid-19 vaccination needs to involve stakeholders to approach the group's anti-vaccine through health promotion strategies such as advocacy, social support, and empowerment.

The safeguarding of pharmaceutical preparations and medical devices is carried out to protect the public from the dangers caused by pharmaceutical preparations and medical devices that do not meet the requirements for quality or safety, or efficacy/benefit. The use of traditional medicines and medicines must be carried out rationally. ${ }^{41}$ Pharmaceutical preparations in the form of drugs and medicinal raw materials must meet Indonesian pharmacopeia or books standard other. Pharmaceutical preparations in traditional medicines and cosmetics and medical devices must meet the specified standards or requirements.

41 Van Norman, G. A, Drugs and Devices: Comparison of European and U.S. Approval Processes, JACC: Basic to Translational Science, Volume 1, Nomor 5, 2016, page.399-412. 
Pharmaceutical preparations and medical devices can only be circulated after obtaining a distribution permit. Labeling and information of pharmaceutical preparations and medical devices must meet objectivity and completeness requirements and not be misleading. The government has the authority to revoke the distribution permit and order the withdrawal from the circulation of pharmaceutical preparations and medical devices that have obtained a distribution license, which is later proven not to meet the quality or safety and usefulness requirements, can be confiscated and destroyed of $\mathrm{n}$ accordance with the provisions of statutory regulations.

Pharmaceutical practices which include manufacturing, including quality control of pharmaceutical preparations, security, procurement, storage, distribution of drugs, drug services for prescription, drug information services, and development of drugs, medicinal ingredients, and traditional medicines, must be carried out by health personnel who have the expertise and authority under the provisions of the legislation. ${ }^{42}$

Furthermore, the punishment for distributing fake vaccines in Indonesia is regulated in Articles 196, 197, 198, and 201 of Act No. 36 of 2009 concerning Health. Anyone who deliberately produces or distributes pharmaceutical preparations or medical devices that do not meet the standards or requirements for safety, efficacy or benefits, and quality as referred to in

Article 98 paragraph (2) and paragraph (3) shall be punished with imprisonment at the most. 10 (ten) years and a maximum fine of IDR 1.000.000.000.00 (one billion rupiahs). Anyone who deliberately produces or distributes pharmaceutical preparations or medical devices that do not have a distribution permit referred to in Article 106 paragraph (1) shall be punished with imprisonment of up to 15 (fifteen) years and a maximum fine of IDR 1.500.000.000. 00 (one billion five hundred million rupiahs). ${ }^{43}$

The ingredients are everyone, deliberately, and producing and circulating vaccine preparations. Everyone, that what is meant by everyone is everyone as a legal subject (supporters of rights and obligations) to which the provisions of Indonesian criminal law apply. Intentionally, the act has been done consciously/there has been an intention from the perpetrator, either to do the act himself, to arise from the act he is about to commit.

They were producing and circulating pharmaceutical preparations (vaccines) that do not meet the standards or requirements for safety, efficacy, or benefits as referred to in Article 98. Whereas what is meant by producing or carrying out the production process is an effort to convert one item into another product or business. To realize a service. In order to make changes and transformations, production factors are needed. Besides that,

42 Grujić, J., Morača, S., \& Fajsi, A, Analysis of Risk Factors in the Channels of Drug Distribution: Professional Perspectives, Sustainability, Volume 12, Nomor 11, 2020, page.2-20.

43 Agustina, E, Criminal Law Policy in Health Care, International Journal of Research in Law, Economic and Social Sciences, Volume 1, Nomor 2, 2019, page.74-80. 
raw materials or semi-finished goods are also needed, transforming into other goods. Production in the pharmaceutical industry must follow the guidelines stated in good drug manufacturing practices (CPOB) to produce medicinal products that consistently meet the quality requirements that have been determined according to their intended use. What is meant by pharmaceutical preparations are drugs, medicinal ingredients, traditional medicines, and cosmetics. The definition of the drug itself is a finished drug that is a preparation or combination of ingredients, including biological products used to influence or investigate systems' physiological or physiological conditions to determine the diagnosis, prevention, healing, recovery, and health improvement. Accordingly, vaccines are pharmaceutical preparations because they are substances or ingredients to prevent a disease for humans.

Every person who does not have the expertise and authority to carry out pharmaceutical practices referred to in Article 108 shall be punished with a maximum fine of IDR $100,000,000.00$ (one million rupiahs). In the case of a criminal act, as referred to in Article 190 paragraph 1, Article 191, Article 192, Article 196, Article 197, Article 198, Article 199, and Article 200 are committed by corporations, in addition to imprisonment and fines against their management, penalties that can be imposed on corporations are in the form of fines with a weighting of three times the criminal fines. In addition to fines as intended, corporations may be subject to additional penalties in the form of revocation of business licenses and revocation of legal entity status.

\section{CONCLUSIONS}

The act against the law of counterfeiting the Covid-19 vaccine in the Health Law is a crime of counterfeiting, that the crime regarding counterfeiting is a crime in which it contains elements of an untrue or false state of an object that something is only from the outside as if it is true when in fact is contrary to the truth. The criminal act of counterfeiting the Covid-19 vaccine is generally regulated in Article 386 Paragraph 1 of the Criminal Code related to acts of fraud and forgery. However, it is specifically regulated in the regulation regarding the punishment for distributing fake vaccines in Indonesia as regulated in Articles 196, 197, 198, and 201 Act No. 36 of 2009 concerning health. The ingredients are everyone deliberately and producing and circulating counterfeit vaccine preparations. Everyone, that what is meant by everyone as a legal subject (supporters of rights and obligations) to which the provisions of Indonesian criminal law apply. Intentionally, that meant is the act has been done consciously/there has been an intention from the perpetrator. Producing and circulating counterfeit vaccine preparations, which produces or carries out the production process, attempts to convert one good into another or realize a service. The science of criminal law distinguishes three kinds of intentionality, namely deliberate intent, deliberate certainty, and deliberate 
action as a possibility. For the criminal act counterfeiting of Covid-19 vaccine by corporate, the corporation can be subject to additional penalties in the form of revocation of business licenses and revocation of legal entity status.

\section{BLIBIOGRAPHY}

\section{Journals:}

Abdualiyeva, A. A., Akhmetsadykov, N. N., Valdovska, A., \& Shanbaev, B. U., Improving the technology of obtaining an inactivated Antirabic vaccine from CVS-11 strain, Research Journal of Pharmacy and Technology, Vo.1 No.12, 2020;

Agustina, E., Criminal Law Policy in Health Care, International Journal of Research in Law, Economic and Social Sciences, Vol.1 No.2, 2019;

Aher, V. D., Banerjee, S., \& Mahaur, K. K., Vaccine: An Ultimate Way of Immunization. Research Journal of Pharmacy and Technology, Vol.4 No.3, 2011;

Ahn, D. G., Shin, H. J., Kim, M. H., Lee, S., Kim, H. S., Myoung, J., Kim, B. T., \& Kim, S. J., Current Status of Epidemiology, Diagnosis, Therapeutics, and Vaccines for Novel Coronavirus Disease 2019 (COVID-19). Journal of Microbiology and Biotechnology, Vol.30 No.3, 2020;

Bhaya, A. G., China Busts Fake COVID-19 Vaccine Ring, Arrests 80, Confiscates 3,000 Doses, CGTN, 2021;

Biradar, V., \& Dalvi, P., Impact of COVID19 on Child Health: Parents Perspective. International Journal of Nursing Education and Research, Vol.8 No.4, 2020;

Clemente-Suárez, V. J., Hormeño-Holgado, A., Jiménez, M., Benitez-Agudelo, J. C., Navarro-Jiménez, E., Perez-Palencia, N., Maestre-Serrano, R., Laborde-Cárdenas, C. C., \& Tornero-Aguilera, J. F., Dynamics of Population Immunity Due to the Herd Effect in the COVID-19 Pandemic, Vaccines, Vol.8 No.2, 2020;

Crommelin, D. J. A., Sindelar, R. D., \& Meibohm, B., Vaccines, Pharmaceutical Biotechnology, Vol.27;

Deshmukh, A., Victim Rights in Indian Criminal Justice System: A Comparative Study, Research Journal of Humanities and Social Sciences, Vol.11 No.2, 2020;

Edytiawarman, E., Muljono, S., \& Arso, D. D., Case Study of Claim Against Violence in Household in Religion Court of Class I a Bengkulu, Bengkoelen Justice: Jurnal I/mu Hukum, Vol.10 No.1, 2020;

Erlandi, G. A., Penyelesaian Perkara Tindak Pidana Terkait Penghinaan Agama, Jurist-Diction, Vol.1 No.2, 2019; 
Fitriani, E., Fake Vaccine in Children and The Protection, Journal La Sociale, Vol1 No.5, 2020;

Ghosh, S., Narcotisation by Media: A Public Perspective of Crime. International Journal of Reviews and Research in Social Sciences, Vol.2 No.1, 2014;

Grujić, J., Morača, S., \& Fajsi, A. (2020). Analysis of Risk Factors in the Channels of Drug Distribution: Professional Perspectives. Sustainability, 12(11), 220. https://doi.org/10.3390/su12114787

Gulpham, S., Biocrime: Neurochemicals in Criminal and Anti-Social Behavior, Research Journal of Science and Technology, Vol.3 No.4, 2011;

Hanley, K. A., The Double-Edged Sword: How Evolution Can Make or Break a LiveAttenuated Virus Vaccine, Evolution: Education and Outreach, Vol.4 No.4, 2011;

Heronia Nendissa, R., Understanding Pancasila in Pela Gandong Culture in Maluku, International Journal of Advanced Research, Vol.8 No.7, 2020;

Interpol. (2020). INTERPOL Warns of Organized Crime Threat to COVID-19 Vaccines. Interpol.Int.

Iswandari, H. D., Aspek Hukum Penyelenggaraan Praktik Kedokteran: Suatu Tinjauan Berdasarkan Undang-Undang No. 9/2004 Tentang Praktik Kedokteran, Jurnal Manajemen Pelayanan Kesehatan, Vol.9 No.2, 2006;

Kaur, S. P., \& Gupta, V., COVID-19 Vaccine: A Comprehensive Status Report, Virus Research, Vol.299 No.198114, 2020;

Kharel, A., Doctrinal Legal Research, SSRN Electronic Journal, Vol.252 No. January, 2018;

Kumar, S., Decriminalization of Adultery: A Step Towards Rights Based Social Relations. Research Journal of Humanities and Social Sciences, Vol.10 No.2, 2019;

Laere, E., Ling, A. P. K., Wong, Y. P., Koh, R. Y., Mohd Lila, M. A., \& Hussein, S., Plant-based Vaccines: Production and Challenges, Journal of Botany, 2016;

Lai, C. C., Shih, T. P., Ko, W. C., Tang, H. J., \& Hsueh, P. R., Severe A Respiratory Syndrome Coronavirus 2 (SARS-CoV-2) and Coronavirus Disease2019 (COVID-19): The Epidemic and the Challenges, International Journal of Antimicrobial Agents, Vol.55 No.3, 2020;

Lee Ventola, C., Immunization in the United States: Recommendations, Barriers, and Measures to Improve Compliance: Part 1: Childhood Vaccinations, $P$ and T, Vol.41 No.7, 2016; 
Nascimento, I. P., \& Leite, L. C. C., Recombinant Vaccines and the Development of New Vaccine Strategies, Brazilian Journal of Medical and Biological Research, Vol.45 No,2, 2012;

Natalis, A., Urgensi Kebijakan Penyelenggaraan Anggaran Pendapatan dan Belanja Daerah dalam Mewujudkan Kesejahteraan Perempuan. Pandecta Research Law Journal, Vol.15 No.1, 2020;

Neuman, P., Some Comments on the Distinction between Intention and Intentionality, Behavior Analyst, Vol.30 No.2, 2007;

Nugroho, D. R., \& Noho, M. D. H., Kajian Yuridis Kewenangan Pemerintah untuk Memerintahkan Melakukan Merger kepada Entitas Bank pada masa Wabah Covid19 dalam Rezim Perdagangan Internasional. Cakrawala Hukum, Vol.22 No.2, 2020;

Pound, R., Justice According to Law, Columbia Law Review, Vol.13 No.8, 1913;

Rakovec-Felser, Z., Domestic Violence and Abuse in Intimate Relationship from Public Health Perspective. Health Psychology Research, Vol.2 No.3, 2014;

Riedel, S., Edward Jenner and the History of Smallpox and Vaccination, Baylor University Medical Center Proceedings, Vol.18 No.1, 2005;

Rithiga, S. B., \& Shanmugasundaram, S., Virtual Screening of Pentahydroxyflavone - A Potent COVID-19 Major Protease Inhibitor, Asian Journal of Research in Pharmaceutical Sciences, Vol.11 No.1, 2021;

Sambrani, Vinod. N., \& Rao, C. S. A., Covid 19 is a Curse to Hospitality Industry. International Journal of Advances in Social Sciences, Vol.8 No.4, 2020;

Satari, H. I., Puspita, M., Sundoro, J., Andrijono, Syafriyal, Sari, R. M., Bachtiar, N. S., \& Hadinegoro, S. R., Safety Profile of Td Vaccination in Indonesian Pregnant Women: A Post-marketing Surveillance Study, Medical Journal of Indonesia, Vol.28 No.4, 2019;

Singh, S. P., Pritam, M., Pandey, B., \& Yadav, T. P., Microstructure, Pathophysiology, and Potential Therapeutics of COVID-19: A Comprehensive Review, Journal of Medical Virology, Vol.93 No.1, 2021;

Sinha, G., The vista of Pandemic in the world and its adaptation by Society: Statistical significant precautions on COVID, Asian Journal of Management, Vol.11 No.4, 2020;

Sun, P., Lu, X., Xu, C., Sun, W., \& Pan, B. Understanding of COVID-19 Based on Current Evidence, Journal of Medical Virology, Vol.92 No.6, 2020; 
Van Norman, G. A., Drugs and Devices: Comparison of European and U.S. Approval Processes, JACC: Basic to Translational Science, Vol.1 No.5, 2016;

Visweswaran, V., Binoy, A., Sreenivas, A., Abhinand, B., \& Vijayan, M., VaccinesPillars of Preventive Health, Research Journal of Pharmacy and Technology, Vol.10 No.9, 2017;

Yadav, R., Vaccines Other Than Specified in National Immunization Schedule among Parents of under- five Children, International Journal of Advances in Nursing Management, Vol.3 No.1, 2015;

Yuningsih, R., Uji Coba CoronaVac dan Rencana Vaksinasi Covid-19 Massal di Indonesia, In Info Singkat: Kajian Singkat Terhada isu Aktual dan Strategis, Vol. XII, No. 16, 2020;

Zhang, G., Yang, H., Zhang, A., Shen, Q., Wang, L., Li, Z., Li, Y., Zhao, L., Du, Y., Sun, L., Zhao, B., Zhu, H., Fu, H., Li, X., Gao, X., Hao, S., Ding, J., Chen, Z., Xu, Z., ... Li, Q., The Impact of the COVID-19 Outbreak on the Medical Treatment of Chinese Children with Chronic Kidney Disease (CKD) : A Multicenter Cross-section Study in the Context of a Public Health Emergency of International Concern, MedRxiv, 2020;

Zheng, J., SARS-CoV-2: An Emerging Coronavirus that Causes a Global Threat, International Journal of Biological Sciences, Vol.16 No.10, 2020; 